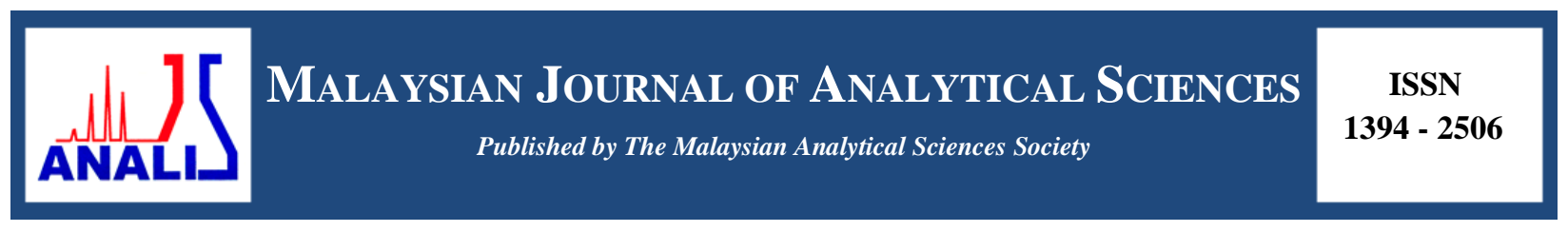

\title{
LASER-ASSISTED SILICON ETCHING FOR MICRO FUEL CELL ELECTRODE PLATE FABRICATION
}

\author{
(Fabrikasi Plat Elektrod Sel Bahan Api Mikro dengan Punaran Silikon Terbantu Laser) \\ Umi Azmah Hasran ${ }^{1 *}$, Siti Kartom Kamarudin ${ }^{1,3}$, Burhanuddin Yeop Majlis², Wan Ramli Wan Daud ${ }^{3}$, \\ Abdul Amir Hassan Kadhum ${ }^{3}$, Gandi Sugandi ${ }^{4}$ \\ ${ }^{1}$ Fuel Cell Institute \\ ${ }^{2}$ Institute of Microengineering and Nanoelectronics \\ ${ }^{3}$ Department of Chemical and Process Engineering \\ Universiti Kebangsaan Malaysia, 43600 UKM Bangi, Selangor, Malaysia \\ ${ }^{4}$ Research Center for Electronics and Telecommunication \\ Lembaga Ilmu Pengetahuan Indonesia, Bandung, Indonesia \\ *Corresponding author: umi.h@ukm.edu.my
}

Received: 13 April 2017; Accepted: 17 April 2018

\begin{abstract}
Silicon electrode plates for micro fuel cells were obtained using a microfabrication process based on the micro-electromechanical system (MEMS) technology. The dry etching process involved the laser ablation technique using the highly stable Nd:YAG. This technique is suitable for micromachining silicon substrates. The total size of the electrode plate was $2.5 \mathrm{~cm} \times 2.5$ $\mathrm{cm}$ and the active reaction area was $1 \mathrm{~cm}^{2}$. An increase in laser scan numbers deepened the groove being etched on the silicon sample, but it showed a saturated behavior as the number of scans became higher. The time required to etch a complete electrode plate flow field with 14 square-shaped through-holes of $0.185 \mathrm{~cm}$ x $0.185 \mathrm{~cm}$ area using laser ablation was $\sim 30$ minutes, which was much shorter than the wet etching time of more than 10 hours with the potassium hydroxide solution $(\mathrm{KOH})$ solution. The laser-etched flow field achieved vertical sidewalls as per the original design, whereas the wet-etched structure achieved a typical anisotropic hole structure with sidewalls that were approximately $54^{\circ}$ to the electrode surface due to the $\langle 100\rangle$ orientation of the silicon wafer. Therefore, the laser ablation technique was chosen to produce the electrode plates for the micro fuel cell as it can save time on the etching process and produce more precise flow field dimensions for the electrode plates with less process steps compared with the conventional wet etching processes using $\mathrm{KOH}$ solution.
\end{abstract}

Keywords: flow field design, MEMS technology, bulk micromachining, dry etching technique, laser ablation

Abstrak
Plat silikon untuk sel ahan api mikro dihasilkan menggunakan proses mikrofabrikasi yang berasaskan teknologi sistem mikroelektro-mekanikal (MEMS) dengan proses punaran kering menggunakan teknik ablasi laser. Jenis laser yang digunakan untuk kerja punaran kering ini adalah Nd:YAG berkestabilan tinggi yang sesuai untuk pemesinan mikro bagi substrat silikon. Saiz keseluruhan plat elektrod yang dihasilkan adalah $2.5 \mathrm{~cm}$ x $2.5 \mathrm{~cm}$, manakala kawasan aktif tindakbalas adalah $1 \mathrm{~cm}^{2}$. Peningkatan bilangan imbasan menjadikan kawasan terablasi pada sampel lebih dalam tetapi punaran menjadi semakin tepu apabila bilangan imbasan semakin meningkat tinggi. Masa untuk memunar habis medan aliran plat elektrod yang mempunyai 14 lubang tembus berbentuk segi empat sama dengan keluasan $0.185 \mathrm{~cm}$ x $0.185 \mathrm{~cm}$ dengan menggunakan laser hanyalah kira-kira 30 minit, berbanding dengan proses punaran basah menggunakan kalium hidroksida (KOH) yang memakan masa lebih 10 jam. Proses yang lama ini juga memerlukan lapisan $\mathrm{SiO}_{2}$ yang lebih tebal sebagai pelindung silikon semasa proses punaran dijalankan. Malah, punaran basah $\mathrm{KOH}$ ke atas wafer silikon dengan orientasi <100> memberi ciri lubang dengan dinding yang bersisi sendeng pada sudut $\sim 54^{\circ}$ dari permukaan plat dan mengakibatkan bukaan lubang mempunyai saiz yang lebih kecil daripada rekabentuk asal. Oleh itu, teknik ablasi laser dipilih untuk menghasilkan plat elektrod bagi mikro sel fuel kerana ia 
dapat menjimatkan masa mikrofabrikasi dan menghasilkan dimensi medan aliran untuk plat elektrod yang lebih tepat dengan langkah aliran proses mikrofabrikasi yang kurang berbanding dengan proses punaran basah menggunakan larutan $\mathrm{KOH}$.

Kata kunci: rekabentuk medan aliran, teknologi MEMS, pemesinan mikro pukal, proses punaran kering, teknik ablasi laser

\section{Introduction}

To design, characterize, and fabricate the electrode plate, electrode flow field is typically downscaled to the microsize level on a silicon plate using the micro-electro-mechanical system (MEMS) micro-machining processes. Bulk micromachining is based on the dry etching method using laser ablation technique. Therefore, it does not have the limitations presented by the etching selectivity and the silicon crystal plane orientation; it also does not need the photolithography process for patterning the design onto the electrode plate. The same flow field design was used to produce the electrode plate structures using the wet etching method with potassium hydroxide solution (KOH) solution. This is the more established and conventional etching method typically used in MEMS fabrication.

Laser ablation is a simple micromachining technique that provides more simplified surface etching data and clear surface morphology [1]. The technique has been used to modify the physical structure of micro fuel cell components, such as gas diffusion layer (GDL), membrane electrode assembly (MEA), and bipolar plates. The transport property related to the two-phase air-liquid flow in ordinary GDL materials was improved by perforating the dual-layer diffusion media used with a laser beam to obtain a water transport channel. Large fixed-sized pores allow capillary diffusion for water transport to occur without the need for significant pressure gradients [2, 3]. The functional surface area of a membrane was reinforced by roughening up the surface using a modified femtosecond laser method, which resulted in compelling morphological effects without altering the membrane's local chemical properties. The coarse surface of the membrane was then coated with a thin layer of catalyst for the MEA, and subsequent performance tests showed that this modification increased catalyst utilization [4]. Meanwhile, selective laser sintering (SLS) is a technique for making additive materials for the graphite composite used in bipolar plates. A powder mixture containing graphite and binder material particles were sintered using laser scans, after which a liquid binder was then used to bind the powder mixture together to form a three-dimensional layer-by-layer structure. Using this approach, complex flow channels could be constructed in a shorter time, and the required cost was lower than the injection molding and compression molding process typically used in producing bipolar plates $[5,6]$.

Conventional microfabrication processes, such as isotropic, anisotropic, electrochemical, and ionic etching, provide limited design options; in comparison, laser ablation can produce almost any form or contour of the required silicon structures [7]. A very fast etching time can be obtained for high-intensity lasers in the gas environment when the appropriate local exposure dose is continuously released onto the silicon in the area to be etched. The operation of different types of gas lasers, such as the Argon-ion laser, Excimer laser, and $\mathrm{CO}_{2}$ laser [8 - 12], depends on its emission wavelength and output power. Laser systems with different laser sources, such as the carbon dioxide $\left(\mathrm{CO}_{2}\right)$ laser [11], Excimer ultraviolet laser [8], Nd:YAG solid-state laser [13-15], Yb:YAG disc laser [9], and Yb fiber laser [1], are also suitable for silicon etching.

However, the energy absorbed by the laser beam can cause the local temperature of the silicon sample to rise, which may lead to the evaporation or melting of the silicon. This is accompanied by the local destruction of crystalline arrays in the area surrounding the melting zone [13]. Laser ablation may also produce undesirable damages, such as heat-affected zones, micro-cracks, and pulse breaks, which can then affect the micro fuel cell performance. The interaction between laser ablation and the surface being etched depends largely on the laser beam parameters, as well as the physical and chemical properties of the silicon. Therefore, proper methods of conducting laser source selection and laser parameter optimization are important to minimize sample damage [14, 16].

\section{Materials and Methods}

The laser system used in this work was the Nd: YAG laser, i.e., GSI Lumonics W670 Laser Trim system (General Scanning Inc., Somerville, US), which is more commonly utilized for applications other than silicon etching due to its high stability. Its photon energy $(1.17 \mathrm{eV})$ exceeds the silicone band gap $(1.12 \mathrm{eV})$ and makes it a suitable choice for micro-machining silicon substrates. Neodymium $\left(\mathrm{Nd}: \mathrm{Y}_{3} \mathrm{Al}_{5} \mathrm{O}_{12}\right)$ is a crystal used as the laser ablation medium, 
where the YAG housing is typically doped with about $1 \%$ (atomic) neodimium [17]. For this study, the laser machine was equipped with an optic pump for the krypton arc lamp that supplied energy to the laser medium, i.e. the YAG rod. It was used together with an optical Q-Switch unit for the laser beam in the $\mathrm{x}-\mathrm{y}$ path direction.

The Nd:YAG laser was pumped using optical means with a flash tube or laser diode and it emitted infrared light with a regular wavelength of $1064 \mathrm{~nm}$. During the laser ablation process, reflective mirrors forced the laser beam through the cavity towards one of the mirrors and then reflected it back to another mirror with further stimulation from the YAG rod. However, when the beam hit the front of the mirror, a small amount of beam was transmitted over the mirror while the rest was reflected into the cavity. This occurred in a continuous wave $(\mathrm{CW})$ and the laser output was never interrupted. The steady energy production was stable and was generated over time, which could have caused an etching process to be irregular due to overheating.

The Q-switch solved this problem as it produced high peak power output that disturbed the optical cavity for a short period of time. When the optical cavity interference occurred, a continuous pumping resulted in the larger population inversion, which caused the pulse to become stronger and its duration to become shorter when the optical cavity was restored. Nonetheless, a YAG laser with a Q-switch could cause many particles to be formed around an etched groove.

Sample orientation has no significant effect on the etching result [18]. In the current work, the sample to be etched was attached to the target holder in a horizontal position. The laser beam angle was perpendicular to the sample surface and the laser's working distance was about $23 \mathrm{~cm}$ from the objective lens. The dimensions of the desired structures were obtained by controlling the specific parameters of the laser system, i.e. the q-rate, bite size, and power input. The scanned patterns on the sample surface was aligned by attaching the sample to the target holder at the same position throughout the ablation process.

The laser machine used a software program for the layout plan. The source files of the program were edited in C language and the GSI-laser language. Different designs had different work plans that were specific to the paths taken by the laser beam and the time required to carry out the ablation process until completion. Using mirrors, the laser scan speed could be controlled to be very fast for high throughput processing. The dry etching process with the laser ablation technique did not require additional chemicals during operation. The samples also did not need to be physically touched until the etching process was completed and this reduced the risk of contamination [16]. The finished electrode plate was then arranged on the cathode side of the micro fuel cell, as shown in Figure 1.

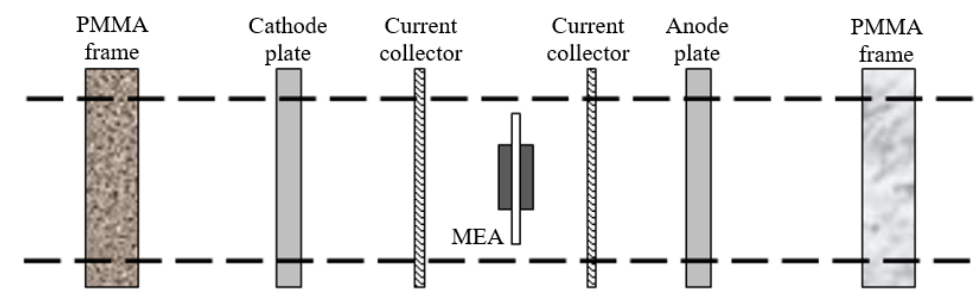

Figure 1. The schematic arrangement of the cathode electrode plate in a single cell assembly

\section{Results and Discussion}

The laser ablation technique did not require photolithography and photomask patterning processes for silicon etching. Figure 2 shows the result of a laser ablation process, in which a heat-affected zone occurred in the area surrounding the etched grooves and damaged the silicon surface. Typically, a silicon dioxide $\left(\mathrm{SiO}_{2}\right)$ layer is naturally formed on the silicon surface exposed to laser ablation in an airy environment. Therefore, it is the most suitable layer to be used for protecting the sample from experiencing severe damage from overheating [19]. A layer of $\mathrm{SiO}_{2}$ was formed using a simple thermal oxidation technique [20] for the actual samples before the etching process was carried out. 


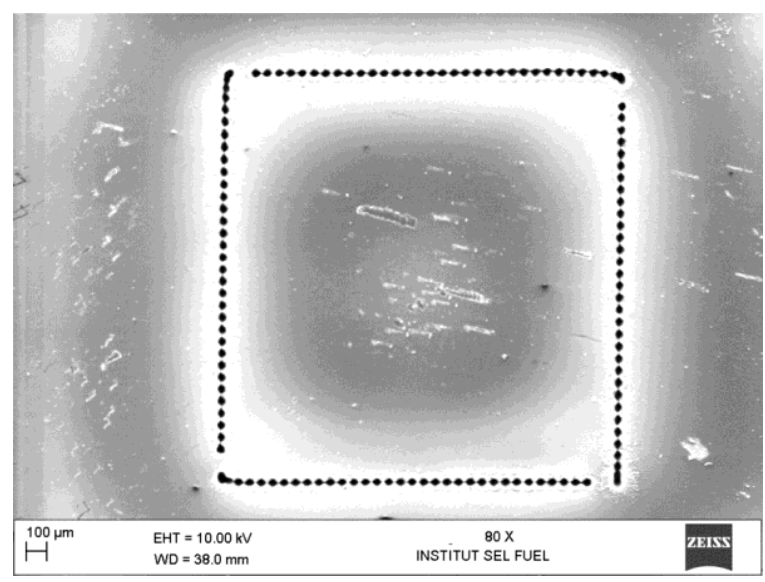

Figure 2. Laser ablation resulting in a heat-affected zone on the silicon surface

The Nd:YAG laser was scanned over the entire target surface according to the designed program to produce the required flow field for the electrode plates. The layout for each etching work design was "serialized", i.e., one scanning program should be completed before the next one began. The length of the sample processing time was dependent on each pattern in the overall design; hence, the patterns must be plotted in the correct order in the planned work sequence. Figure 3 shows a 4-inch diameter silicon wafer that was lightly scratched with a laser beam for mechanical breaking [21] to obtain blank samples of $2.5 \mathrm{~cm} \times 2.5 \mathrm{~cm}$ size. The process flow to produce the required electrode flow field is given in Figure 4.

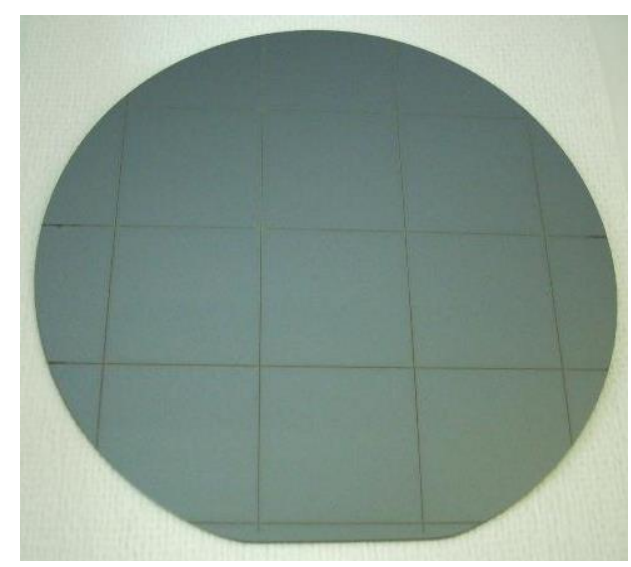

Figure 3. Scratch marks from the laser ablation technique on the oxidized 4 -inch diameter wafer to produce $2.5 \mathrm{~cm}$ $\times 2.5 \mathrm{~cm}$ blank samples for the electrode plates 


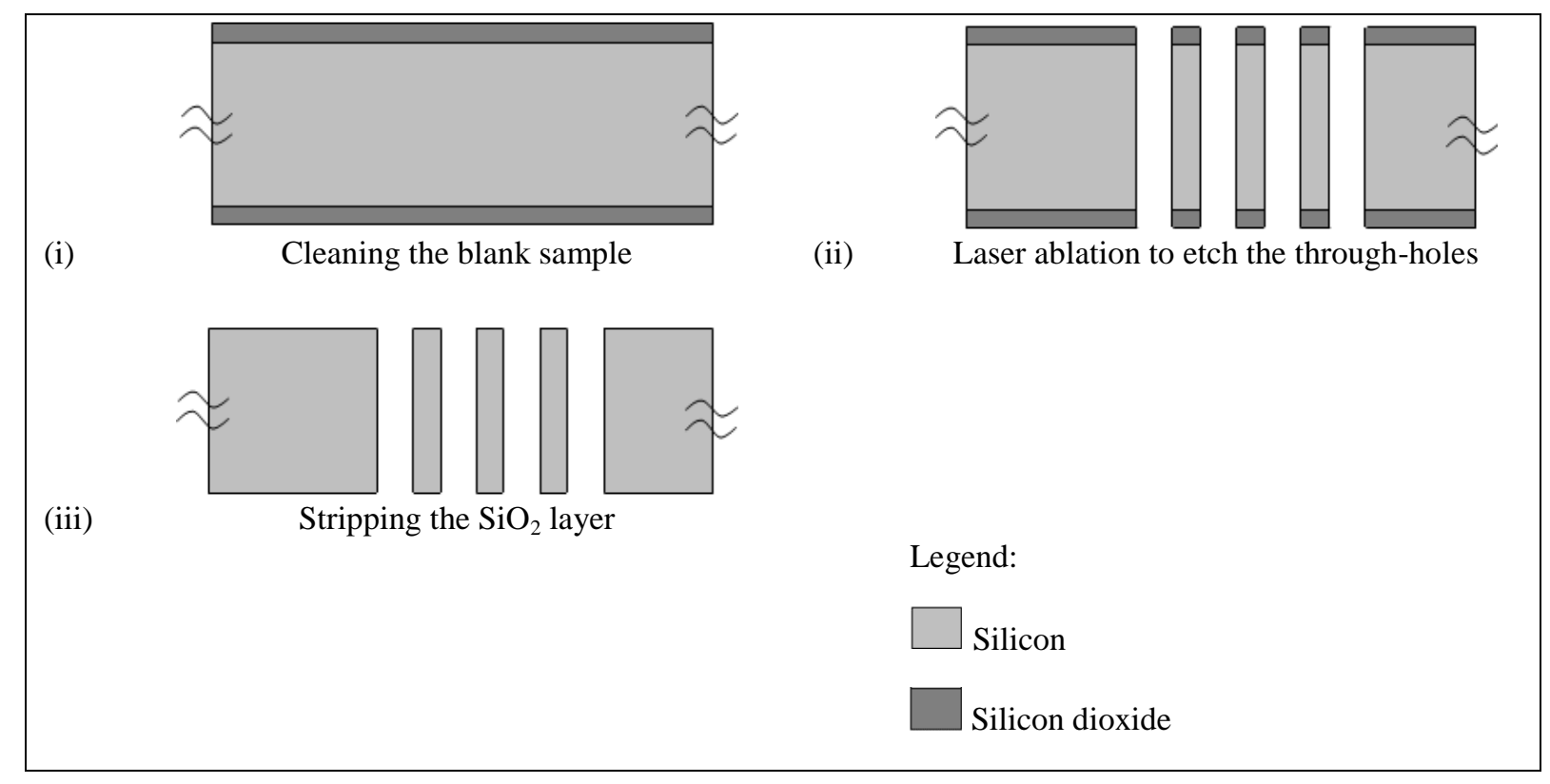

Figure 4. The laser ablation process flow for the electrode flow field microfabrication

Figure 5(a) shows that the bit size, i.e., the distance covered by the beam between the grooves, and the midpoint of the actual laser beam diameter, which controls the degree of the beam overlap, could be modified to adjust the distance between the pulse locations in the vertical ( $v$ ) and horizontal $(w)$ directions. The $q$-rate, i.e., the number of grooves etched per second, was set at a value of $1 \mathrm{kHz}$ to produce the desired surface texture. The laser pulses could be separated to form the programmed flow field pattern by manipulating the number of scans at each pulse point. Hence, the coordinates of the pulse starting points and the directions of travel for the laser beam were programmed before the laser ablation process was carried out. The $(0,0)$ coordinate was set on the bottom-left corner of the electrode plate. A $1 \mathrm{~cm} \times 1 \mathrm{~cm}$ area was lightly etched to mark the active reaction site for the MEA. The coordinate details for each of the 14 starting points were specified in the laser program to produce the square-shaped throughholes flow field in the array shown in Figure 5(b) to give a 50\% MEA active area utilization for the micro fuel cell.
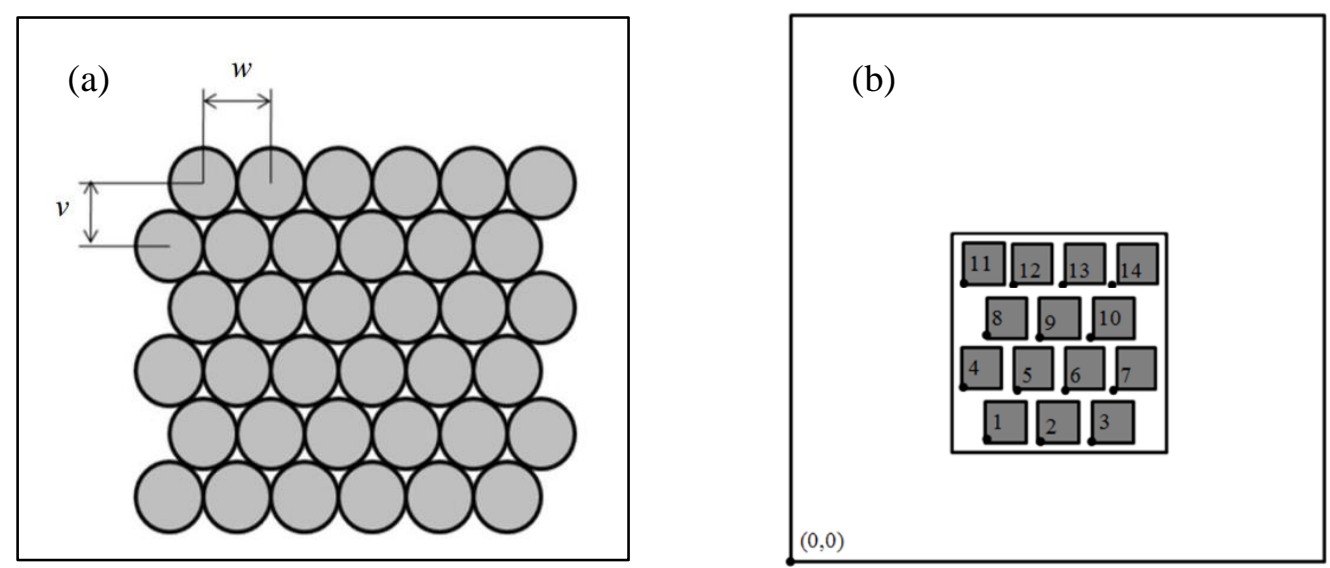

Figure 5. Laser ablation work plan to etch the electrode plate: (a) schematic of the planned beam path for the laser pulses and (b) the through-holes flow field array 
The etched depth relationship was plotted as a function of laser ablation at $100 \%$ power, $2 \mathrm{kHz}$ q-rate, and 2 mil bit size. All samples were taken from the same batch so that the silicon surface finish, clarity, reflection and refraction could be considered as being within the same range. The graph of the groove depth measurements over the number of laser scans, or ablation number, is shown in Figure 6. As can be seen, the increase in the number of laser scans caused the ablated groove to become even deeper. However, the curve of this inclination is not a straight line, indicating that the etching process becomes less effective at an even higher number of scans. This saturated behavior is in accordance with the laser ablation activity for silicon [1].

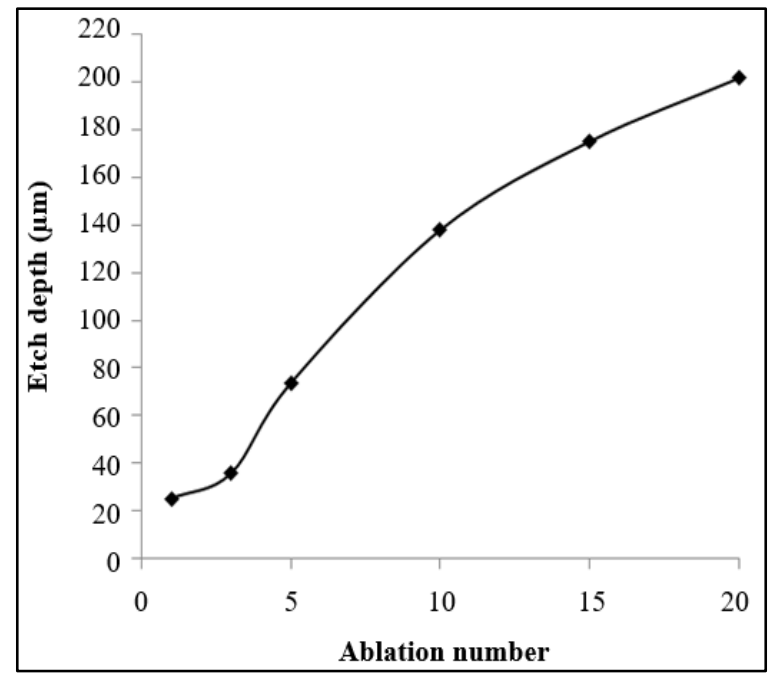

Figure 6. The relationship between the etched groove depth and the ablation number

This saturation behavior can be described as follows. The continuously etched groove caused the melted silicon material, which interacted with the laser beam, to gain mass. As the depth of the ablated area increased, the melted silicon was trapped in the form of ejecta mounds, which then absorbed and scattered most of the laser energy. As the mounds hardened and formed slags around the groove, further ablation was fended off. The movements of the ablated silicon material became more difficult, leading to the condensation of the material inside the groove. In fact, when the etched region moved further into the wafer, its lowest point gradually deviated from the laser beam focal plane. This reduced the effectiveness of the laser beam energy and the etching rate [1,18]. The scanning electron micrograph (SEM) of the cross-section of the ablated region in Figure 7 shows a clear morphology of the etched structure, which indicates a non-uniform depth within the etched region that is possibly derived from the generally uneven laser energy distribution. This observation also shows that the flow field depth can be adjusted by controlling the number of laser scans carried out in the ablation process. A more serious microscopic erosion can be observed from the first laser beam that impacted the silicon surface compared with the subsequent ones.

The through-holes in the flow field shown in Figure 5(b) required about 55 laser scans to be completed. The silicon surface could be damaged by the formation of slags during the etching process, and this might reduce the electrical performance of the electrode plate when employed in a micro fuel cell. However, as the slags were deposited on top of the $\mathrm{SiO}_{2}$ layer that was used as the etching mask, they could be easily cleaned after the ablation process was completed by immersing the sample in a buffered oxide etch (BOE) solution at room temperature without stirring or undergoing ultrasonic cleaning, followed by a DI water rinse. The cleaning time for the process shown in Figure 8 took 30 seconds and required at least a very thin $25 \mathrm{~nm} \mathrm{SiO}_{2}$ layer for protection. 


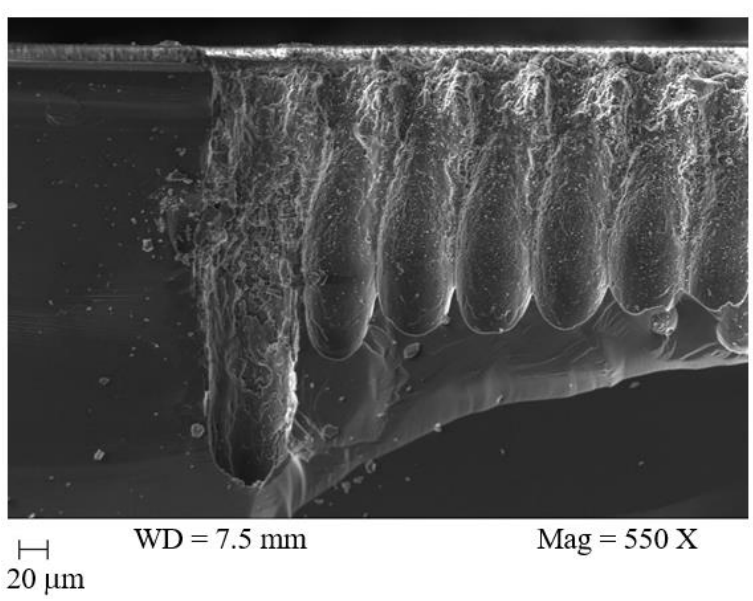

Figure 7. The ablated region cross-section after 20 laser scans

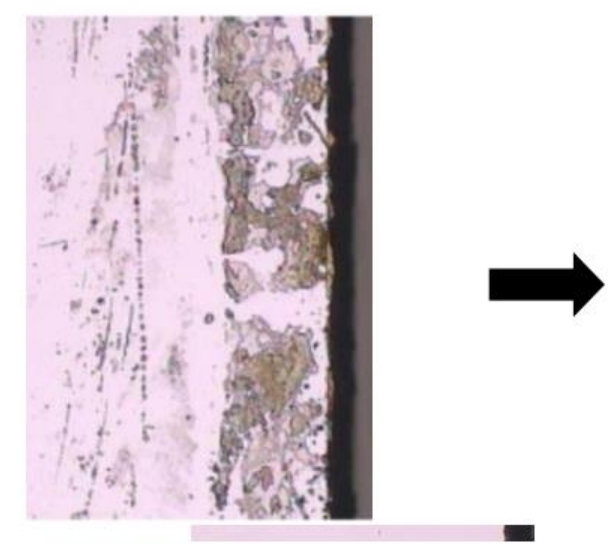

Figure 8. Slag cleaning on the surface of the oxidized sample surface that underwent laser ablation

In case of a serious slag formation, the ablated area should be briefly dipped in a $\mathrm{KOH}$ solution of $30 \%(\mathrm{w} / \mathrm{w}$ ) concentration mixed with IPA $1 \%(\mathrm{v} / \mathrm{v})$ at $80{ }^{\circ} \mathrm{C}$ to remove the laser slags and smoothen the sample surface. Figures 9 (a) and (b) show a comparison between the flow field structure produced by a $\mathrm{KOH}$ wet etching process and by a dry etching process using laser ablation, respectively. The micromachined flow field in the cathode plate allows for the effective delivery of oxygen to the active area of the MEA. The $\mathrm{SiO}_{2}$ layer was later stripped using a $10 \%$ (v/v) hydrofluoric acid (HF) solution to obtain the final sample. No micro cracks were observed on the surface of the sample. Nonetheless, micro cracks have an insignificant effect on the micro fuel cell performance in terms of electricity generation, if the electrical contact via a conductive layer for current collection was maintained on the overall sample surface. 


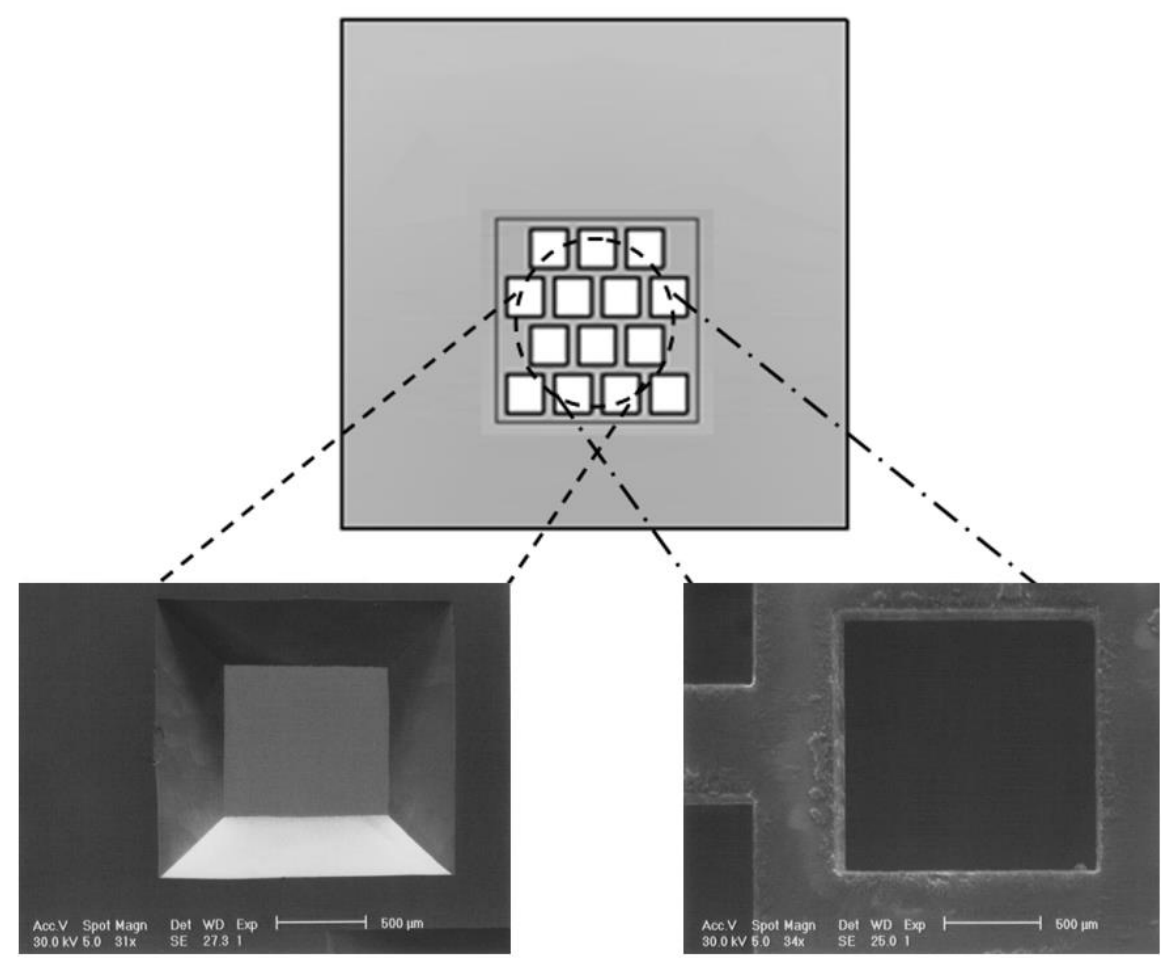

(a)

(b)

Figure 9. Comparison between the flow field patterns and structures produced by: (a) a $\mathrm{KOH}$ wet etching process and (b) a dry etching process using laser ablation

The time taken to complete the process of etching 14 through-holes of $0.185 \mathrm{~cm} \times 0.185 \mathrm{~cm}$ area was more than 10 hours for the $\mathrm{KOH}$ wet etching process. The anisotropic $\mathrm{KOH}$ solution also displays characteristic $\mathrm{V}$-sided sidewalls at an angle of $\sim 54^{\circ}$ from the $\langle 100\rangle$ silicon plate surface, resulting in smaller-sized openings for reactant transport. The difference between the designed hole and the laser-etched hole is $28.6 \%(0.132 \mathrm{~cm}$ hole width and length), whereas the wet-etched hole yields a difference of $10.3 \%$ (i.e., $0.166 \mathrm{~cm}$ hole width and length for the larger opening) and $49.5 \%$ (i.e., $0.166 \mathrm{~cm}$ hole width and length for the smaller opening). Therefore, laser ablation is the preferred process because of two reasons: (1) the through-holes resemble the original flow field design and (2) the time taken to complete the dry etching process for the all the holes was only about 30 minutes. Further comparisons of the $\mathrm{KOH}$ etching and laser ablation processes in Table 1 show the weaknesses and advantages from the practical point of microfabrication and the planned design of the electrode flow field.

Table 1. Comparisons between the dry etching process with laser ablation and the wet etching process with $\mathrm{KOH}$ solution in terms of microfabrication and planned design of the electrode flow field

\section{KOH etching}

- The etching time was very long and required a much thicker $\mathrm{SiO}_{2}$ layer of about $6 \mu \mathrm{m}$ to protect the silicon surface during the process.

- It required the complex and time-consuming photolithography process to effectively transfer the flow field pattern onto the silicon plate surface. There was also the risk of generating inaccurate patterns during the photo mask alignment step.

\section{Laser ablation}

- A thin $\mathrm{SiO}_{2}$ layer of about $25 \mathrm{~nm}$ was considered adequate to protect the silicon surface during the process.

- The photolithography process was not needed. The flow field pattern was precisely etched using the software program for the laser system. 
- The etching time was used as the main technique to control the flow field structure and depth. Therefore, overetching might occur and result in incorrect structures being produced in the process.

- The etching process was low cost as it only required the widely available $\mathrm{KOH}$ solution and a common cleanroom facility.

- It was time-consuming, especially if the times required to complete the prior processes of thermal oxidation and photolithography were added to the total running time required.

- The anisotropic etching characteristics of $\mathrm{KOH}$ produced slanted sidewalls for the through-holes structure, which limited the process capability in following the design.
- The software program could be easily changed before and during the etching process to obtain the pattern and depth required for the flow field.

- The etching process was costly as it required a laser system that was suitable for silicon etching. This system may not be easily available in any cleanroom facility.

- The total time needed to complete the etching process for the electrode plate was short (i.e., 30 min) and it also did not require the thermal oxidation and photolithography processes.

- The desired vertical sidewalls of the through-holes required by the design could be produced accordingly.

\section{Conclusion}

The dry etching process using laser ablation technique can be used to produce the desired flow field structure on the electrode plate for micro fuel cells. Compared with the conventional method of wet etching with the KOH solution, dry etching process using laser ablation technique was more successful in etching the required through-holes according to the planned design with shorter etching time. However, microfabrication using the $\mathrm{KOH}$ wet etching process in this work was deemed important because it is a typical low-cost, easy-to-run process for silicon fabrication that can be carried out in common cleanroom facilities.

\section{Acknowledgments}

The authors gratefully acknowledge the financial support for this work given by the Malaysian Research University Grant (GUP-2016-039) and the Ministry of Higher Education (Malaysia) Research Grant (FRGS/1/2016/TK09/UKM/03/1). The research was conducted with full technical support and assistance by the staff at the Fuel Cell Institute Laboratory (Universiti Kebangsaan Malaysia), IMEN-MEMS Fabrication Laboratory (Universiti Kebangsaan Malaysia), Microelectronic Fabrication Laboratory (Universiti Malaysia Perlis), and the LIPI Research Center for Electronics and Telecommunication Laboratory (Bandung, Indonesia).

\section{References}

1. O'Neill, W. and Li, K. (2009). High-quality micromachining of silicon at $1064 \mathrm{~nm}$ using a high-brightness MOPA-based 20-W Yb fiber laser. IEEE Journal of Selected Topics in Quantum Electronics, 15(2): 462 - 470.

2. Gerteisen, D. (2010). Transient and steady-state analysis of catalyst poisoning and mixed potential formation in direct methanol fuel cells. Journal of Power Sources, 195(19): $6719-6731$.

3. Manahan, M. P., Hatzell, M. C., Kumbur, E. C. and Mench, M. M. (2011). Laser perforated fuel cell diffusion media. Part I: Related changes in performance and water content. Journal of Power Sources, 196(13): 5573 5582.

4. Whitacre, J. F., Murphy, R. D., Marrie, A. and Yalisove, S. M. (2009). Enhanced catalyst utilization in PEM fuel cells via ultrafast laser modification of the polymer exchange membrane surface. Electrochemistry Communications, 11(3): $655-659$.

5. Bourell, D. L., Leu, M. C., Chakravarthy, K., Guo, N. and Alayavalli, K. (2011). Graphite-based indirect laser sintered fuel cell bipolar plates containing carbon fiber additions. CIRP Annals - Manufacturing Technology, 60(1): $275-278$.

6. Guo, N. and Leu, M. C. (2012). Effect of different graphite materials on the electrical conductivity and flexural strength of bipolar plates fabricated using selective laser sintering. International Journal of Hydrogen Energy, 37(4): $3558-3566$.

7. Petersen, K. E. (1982). Silicon as a mechanical material. Proceedings IEEE, 70(5): $420-457$. 
8. Long, Y., Xiong, L., Shil, T. and Tang, Z. (2007). Study of excimer laser electrochemical etching silicon. The $2^{\text {nd }}$ IEEE International Conference on Nano/Micro Engineered and Molecular Systems, Bangkok, Thailand.

9. Trusheim, D., Schulz-Ruhtenberg, M., Baier, T., Krantz, S., Bauer, D. and Das, J. (2011). Investigation of the influence of pulse duration in laser processes for solar cells. Physics Procedia, 12, Part B: $278-285$.

10. Allard, M., Boughaba, S. and Meunier, M. (1997). Laser micromachining of free-standing structures in $\mathrm{SiO}_{2}-$ covered silicon. Applied Surface Science, 109-110(0): 189 - 193.

11. Chung, C. K., Wu, M. Y., Wu, J. C., Sung, Y. C. and Huang, G. R. (2006). Silicon micromachining by $\mathrm{CO}_{2}$ laser. The $1^{\text {st }}$ IEEE International Conference on Nano/Micro Engineered and Molecular Systems, Zhuhai, China.

12. Chung, C. K., Wu, M. Y., Hsiao, E. J. and Sung, Y. C. (2007). Etching behavior of silicon using $\mathrm{CO}_{2}$ laser. The $2^{\text {nd }}$ IEEE International Conference on Nano/Micro Engineered and Molecular Systems, Bangkok, Thailand.

13. Alavi, M., Büttgenbach, S., Schumacher, A. and Wagner, H. J. (1991). Laser machining of silicon for fabrication of new microstructures. Proceedings IEEE Transducers'91: 512 - 515.

14. Minami, K., Wakabayashi, Y., Matsubara, T., Yoshimi, K., Yoshida, M., and Esashi, M. (1993). YAG laser assisted etching for releasing silicon micro structure. Proceedings IEEE MEMS '93: 53-58.

15. Lerner, B., Perez, M. S., Toro, C., Lasorsa, C., Rinaldi, C. A., Boselli, A. and Lamagna, A. (2012). Generation of cavities in silicon wafers by laser ablation using silicon nitride as sacrificial layer. Applied Surface Science, 258(7): $2914-2919$.

16. Du, Z., Palina, N., Chen, J., Hong, M. and Hoex, B. (2012). Rear-side contact opening by laser ablation for industrial screen-printed aluminium local back surface field silicon wafer solar cells. Energy Procedia, 25: $19-$ 27.

17. Koechner, W. (2006). Solid-State Laser Engineering (6 edition). London: Springer Ltd.

18. Yuan, W. and Ma, B. (2008). Micro-machinability of monocrystal silicon by direct etching using excimer laser. Journal of Materials Processing Technology, 200(1): 390 - 397.

19. Mizeikis, V., Juodkazis, S., Ye, J.-Y., Rode, A., Matsuo, S. and Misawa, H. (2003). Silicon surface processing techniques for micro-systems fabrication. Thin Solid Films, 438-439(0): $445-451$.

20. Hasran, U. A., Kamarudin, S. K., Daud, W. R. W., Majlis, B. Y., Mohamad, A. B. and Kadhum, A. A. H. (2011). A simple thermal oxidation technique and $\mathrm{KOH}$ wet etching process for fuel cell flow field fabrication. International Journal of Hydrogen Energy, 36(8): 5136 - 5142.

21. Ogorodnikov, A. I. (2016). Finite-element simulation of scratching on a coated brittle plate. AIP Conference Proceedings, 1785(1): 030020. 